\title{
The rise and fall (?) of the digital natives
}

\author{
Terry Judd \\ Department of Medical Education, The University of Melbourne
}

\begin{abstract}
Building on the earlier net generation and millennials concepts, Prensky popularised the notion of a generation of "digital native" students through his 2001 two-part series "Digital natives, digital immigrants". Although his ideas about how students perceive and utilise technology resonated with many educators, they lacked supporting evidence. Subsequent investigations, which informed the so-called "digital natives debate", produced largely contrary evidence and dissenting views. As dissemination and acceptance of this evidence grew, interest in the idea of students as digital natives should have waned. However, a detailed analysis of general and academic search data and of articles published in leading educational technology journals (between 1998 and 2017) suggests that this interest remains strong. Although references to digital natives and the related terms net generation and millennials in educational technology journals has declined somewhat (having peaked in 2011), public and general academic search interest in these terms - and presumably the ideas that underpin them - continues to grow. These trends are discussed from an historical perspective, considering how our acceptance (or rejection) of the digital natives concept has developed, and the potential past, present and future impact of this on technology adoption and implementation practices within our universities.
\end{abstract}

\section{Introduction}

In 2001, Prensky (2001a,b), drawing on the net generation and millennials concepts championed by Tapscott (1998) and Howe and Strauss (2000), wrote about and popularised the idea of a generation of "digital natives". Although the attributes ascribed to each of these generational constructs varied somewhat, the key claims around them were similar (Smith, 2012); the most prominent and often repeated being that digital natives/the net generation/millennials are seasoned users of technology who are innately or inherently tech savvy, and that they behave and think differently because of their use of technology.

Although Prensky's, Tapscott's and Howe and Strauss' ideas were eagerly embraced by the popular media, it wasn't until 2005 and the publication of Oblinger, Oblinger, and Lippincott's (2005) work in "Educating the Net Generation" that they started to gain traction in the academic and educational communities. Some of these ideas clearly resonated with educators - many of whom no doubt had first-hand experience of students who appeared to fit, at least superficially, the stereotypical digital natives profile.

Criticisms of the digital natives concept soon emerged, however, as researchers began to gather evidence, particularly around the first key claim - that they are seasoned and inherently capable users of technology. Large-scale surveys of students' adoption and use of various technologies clearly established that while some students appeared to fit the profile (or something like it), many did not, and that there was considerable variation in the level of technology adoption across student populations (Hargittai, 2010; Jones, Ramanau, Cross, \& Healing, 2010; Kennedy, Judd, Churchward, Gray, \& Krause, 2008; Kennedy, Judd, Dalgarno, \& Waycott, 2010; Margaryan, Littlejohn, \& Vojt, 2011). While adoption rates of a limited number of technologies were indeed high (e.g., laptops, mobile phones; Facebook, email), others were patchy, and many students were not actively involved in the creation of digital content (Kennedy et al., 2007; Margaryan et al., 2011). Moreover, the supposed generational technological gulf between students and their teachers did not appear to be as wide or as deep as painted by Prensky and others (Kennedy, Judd et al., 2008b).

More comprehensive assessments of evidence for and against digital natives and their supposed capabilities soon followed, with the review by Bennett, Maton, and Kervin (2008) being the first and most often cited of these. In particular, they addressed the idea that digital natives' technical preferences and capabilities 
demanded a fundamentally different approach to their teaching and learning. While drawing on the work of Kennedy and others (Kennedy, Judd et al., 2008; Oliver \& Goerke, 2007) to accept that a proportion of students are indeed technically adept, they argued that consideration of these students' preferences and expectations did not necessitate profound educational change. They also made the important and often overlooked point that the role and importance of technology in students' lives outside and inside of school and university can be quite different, and that we should be wary of generalising from one to the other. Perhaps the clearest case of this is students' use of social media, particularly Facebook. Facebook enjoys extremely high overall adoption rates among school and university student populations and supports one-to-many and many-to-many collaboration, making it a strong candidate for educational use. However, many students also view it as a primarily personal and social technology; something they would prefer to keep separate from their academic lives (e.g., Ivala \& Gachago, 2012; Madge, Meek, Wellens, \& Hooley, 2009; Mok, 2012; Ophus \& Abbitt, 2009). Although some students do use Facebook to support their studies, most of this use is informal and unregulated with no or limited involvement or oversight by teaching or administrative staff (Gray, Annabell, \& Kennedy, 2010; Lampe, Wohn, Vitak, Ellison, \& Wash, 2011; Madge et al., 2009; Selwyn, 2009b).

Bennett et al. (2008) also exposed a major disconnect between the confidence surrounding the claims by Prensky and others about digital natives and actual evidence in support of these claims - a finding echoed by others in subsequent studies and reviews (e.g., Bennett \& Maton, 2010; Koutropoulos, 2011; Selwyn, 2009a; Smith, 2012; Thompson, 2013). Although the notion of a homogenous and technologically adept generation of students was quickly debunked, the idea - championed most strongly by Prensky (2001b) - that students not only acted but thought differently, because of cognitive changes brought about through their use of technology, persisted. The proposal here is that in the face of persistent and pervasive use of technology, the recognised capacity of the brain to adapt to repeated stimuli - that is, neural plasticity - renders such changes inevitable. Prensky viewed these potential adaptations as largely positive ones, enabling digital natives to excel at online multitasking, information gathering and collaboration. Arguments against the homogeneity of technology experience aside, it seems clear that potential cognitive or behavioural changes can have negative as well as positive aspects, particularly when it comes to learning.

On the positive side, multitasking practice has been shown to improve multitasking performance on simple repetitive tasks (Dux et al., 2009). But, multitasking has also been shown to negatively impact on memory encoding and learning and to increase distractibility (Loh \& Kanai, 2015; Moisala et al., 2016; Ophir, Nass, \& Wagner, 2009; Trafton \& Monk, 2007), leading to recommendations that students actively limit their multitasking during study (Judd, 2015; Rosen, Carrier, \& Cheever, 2013). Similarly, although the amount of quality online information available to students is both increasing and becoming easier to access, brain imaging studies suggest that use of and reliance on this information can lead to poor retention and shallow processing of information (Loh \& Kanai, 2015). Easier access to (and preference for) non-scholarly online information might even exacerbate this process (Catalano, 2013; Judd \& Kennedy, 2011). Social media use is often linked to positive outcomes, for example, helping users to develop and maintain social capital and selfesteem (Ellison, Steinfield, \& Lampe, 2007, 2008). However, it has also been associated with negative emotions among younger users (Hayes, van Stolk-Cooke, \& Meunch, 2015), poorer academic outcomes (Junco, 2012; Karpinski, Kirschner, Ozer, Mellott, \& Ochwo, 2013; Kirschner \& Karpinski, 2010) and even depression and anxiety among some users (Becker, Alzahabi, \& Hopwood, 2013; Rosen, 2012). When we consider that technology use is only one of many potential factors that influence the way we behave, think and learn, it would seem difficult to embrace Prensky’s positive view of the technology-enhanced digital native brain, let alone fundamentally alter our teaching practices to accommodate it. 


\section{Persistence of ideas about digital natives}

Despite a lack of evidence in favour of many of the key claims relating to digital natives, and a body of evidence against, many authors continue to either adopt, acknowledge or uncritically quote Prensky's ideas. For example:

It may be that students simply have the skills necessary to connect masses of apparently unrelated data into a whole because they have been training these skills for many years. Perhaps digital natives simply do not have the problems that can be expected in older generations. (Nouns, Montagne, \& Huwendiek, 2015, p. 450)

According to Prensky (2001) 'today's students are no longer the people our educational system was designed to teach' (p. 8). They should be approached as 'digital natives' being more familiar and comfortable with the use of technology than with traditional lecturing methods. (Katai, 2015, p. 290)

Growing up in the information age, undergraduates in the 21st century are all digital natives (Prensky, 2001), with mobile communication and online social networks widespread among them. (Ding \& Stapleton, 2015, p. 672)

It is only through this way we can truly engage our students who are digital natives of the 21st century. (Xiang \& Liu, 2016, p. 76)

We have a reasonably good understanding of how and why these ideas gained currency (see Bennett et al., 2008), but why do they persist?

In their review, Bennett et al. (2008) used the term moral panic - a sociological concept - to describe public and educator concern around digital natives, in the absence of any real evidence for action. Perhaps more of a moral disquiet than a panic now, the general notion, that an idea or theory persists in the face of mounting evidence to the contrary, remains. In their subsequent paper, Bennett and Maton (2010) further characterised the debate (in favour of digital natives) as a certainty-complacency spiral. According to them, the spiral describes how uncritical promulgation of an idea or information that is undeserved (e.g., lacking supporting evidence) amplifies its significance. In the case of digital natives, they argue that this occurs when authors cite papers that either make unsubstantiated claims themselves or uncritically restate or adopt such claims by others. Additional concepts that might equally apply to acceptance of premises related to the digital natives debate include illusory correlation, where a relationship between variables (i.e., students and technology use) is perceived where none exists and can lead to the development of stereotypes; confirmation bias, where there is a tendency to seek and interpret information in a way that confirms existing beliefs (e.g., arguments put forward by climate sceptics); and cognitive inertia, where there is a tendency to rely on familiar assumptions and a failure to revise them in the face of contrary evidence (Hamilton \& Rose, 1980; Nickerson, 1998; Tripsas \& Gavetti, 2000).

All of these behaviours could help to perpetuate the digital natives concept among some educators, but in light of the strength of the evidence against, we might still expect acceptance and use of the terms digital natives, net generation and millennials to have declined over time. Critical studies started to emerge from 2006 onwards (Ashton \& Newman, 2006; Kennedy, Krause, Judd, Churchward, \& Gray, 2006; Oliver \& Goerke, 2007), and were quite prominent during the period between 2008 and 2010 (Bennett \& Maton, 2010; Bennett et al., 2008; Hargittai, 2010; Helsper \& Eynon, 2010; Jones et al., 2010; Kennedy, Dalgarno et al., 2008a; Kennedy, Judd et al., 2008; Selwyn, 2009a). Moving forward a few years, what level of acceptance do the ideas associated with digital natives (and the net generation and millennials) still enjoy, and how does this relate to previous levels? As the title of this paper asks, are digital natives, or at least the ideas that embody them, still ascendant or are they in decline? 
The aim of this paper then, is not to rehash old or introduce new arguments for or against the existence of digital native, net generation or millennial students, but to track and assess the adoption and acceptance of these terms and the characteristics they purportedly embody over time - from when they were introduced until the present. This is done by drawing on and assessing a range of public or readily accessible academic information, using simple techniques that are available to most researchers. This assessment should be of particular interest to educational technology researchers and practitioners interested in reviewing or reflecting on their own or their institutions' adoption and implementation of learning technologies in the years since Prensky's ideas were popularised.

\section{Methods and results}

A range of approaches was used to assess general and academic interest in and use of the terms digital natives, net generation and millennials over time. The period of interest spans the years 1998 to September 2017 and covers and post-dates the publication of the three seminal articles and books that either coined or popularised the terms - Tapscott's (1998) book Growing up digital: The rise of the Net Generation, Howe and Strauss' (2000) book Millennials rising: The next great generation and Prensky's (2001a) article "Digital natives, digital immigrants: Part 1". Tapscott's use of the term millennials in his 1998 book predates Howe and Strauss' (2000) work but theirs is more often associated with the term and has been cited almost as many times as Tapscott's. The presented data are drawn primarily from Google Trends (https://trends.google.com/trends/) and Google's main search tool (https://google.com) and the Google Scholar academic search tool (https://scholar.google.com), and include some content analysis of academic resources discovered through Google Scholar. Although each of the described methods had a different focus, their overall purpose was to document the rise and fall in interest, appropriation and acceptance of the three terms (and their underlying assumptions) overall and relative to each other and over time.

\section{Assessing overall interest in digital natives, the net generation and millennials}

Interest in the three terms within the general population was assessed using the Google Trends service. Google Trends provides data on the frequency of use of various search terms entered into Google's main search tool, providing a graphical comparison of the popularity of competing search terms over time. All comparisons are relative rather than absolute so that the results for a single search term or phrase will generate a series of daily or monthly values (depending on the time frame) between 0 and 100 over the specified interval. Where multiple search terms or phrases are entered, the most popular term will be scaled between 0 and 100 and all other search terms scaled relative to it.

A Google Trends analysis was conducted using the search terms digital natives, net generation and millennials for the period January 2004 to September 2017. Unfortunately, Google Trends only reports on search data collected from January 2004 onwards, meaning that it could not be used to assess interest in digital natives, the net generation and millennials prior to this date, around and soon after the time that Tapscott (1998), Howe and Strauss (2000) and Prensky's (2001a) original books and articles were published. The plural forms of both digital native and millennial were employed in this and all subsequent analyses so as to refer to generational or collective rather than individual use of the terms. In the case of millennials this also reduces the likelihood of its inclusion where it has been used in alternative contexts (i.e., objects or events related to the turn of the century more generally). The results of this analysis are presented in Figures 1 to 3 . The analysis is split over three figures to allow for the relative scaling of the results, which due to the rapid expansion of interest in millennials over the last few years, would have failed to register year-to-year variation in search interest in digital natives and net generation if all three terms were plotted together over the entire period. Figure 1 illustrates the relative search frequencies of all three search terms over the 10 years from January 2004 to January 2014. Figure 2 (digital natives versus net generation) and Figure 3 (millennials only) cover the remaining period to September 2017. Relative interest in each of the three terms over the period February 2014 to September 2017 can be estimated by using the final values in Figure 1 as starting points. 
Figure 1 reveals that interest in the net generation was initially strongest, with much lower levels of interest in digital natives and millennials. There was a spike in interest in millennials late in 2007, bringing it in line with net generation. Interest in digital natives peaked in early 2010, remained relatively constant between 2010 and 2014, and has declined slowly since then (Figure 2). Interest in the search term net generation peaked early on and then declined gradually until about 2012. It then remained relatively stable before rising during late 2016 to early 2017 and again in September 2017. After remaining relatively stable between late 2007 and early 2010, interest in millennials mushroomed, and by the end of 2013 was running at up to 10 times that for either digital natives or net generation. It continued to rise throughout the remainder of the search period (Figure 3), and by September 2017 was running at around 40 times the level of net generation, and up to 70 times that of digital natives.

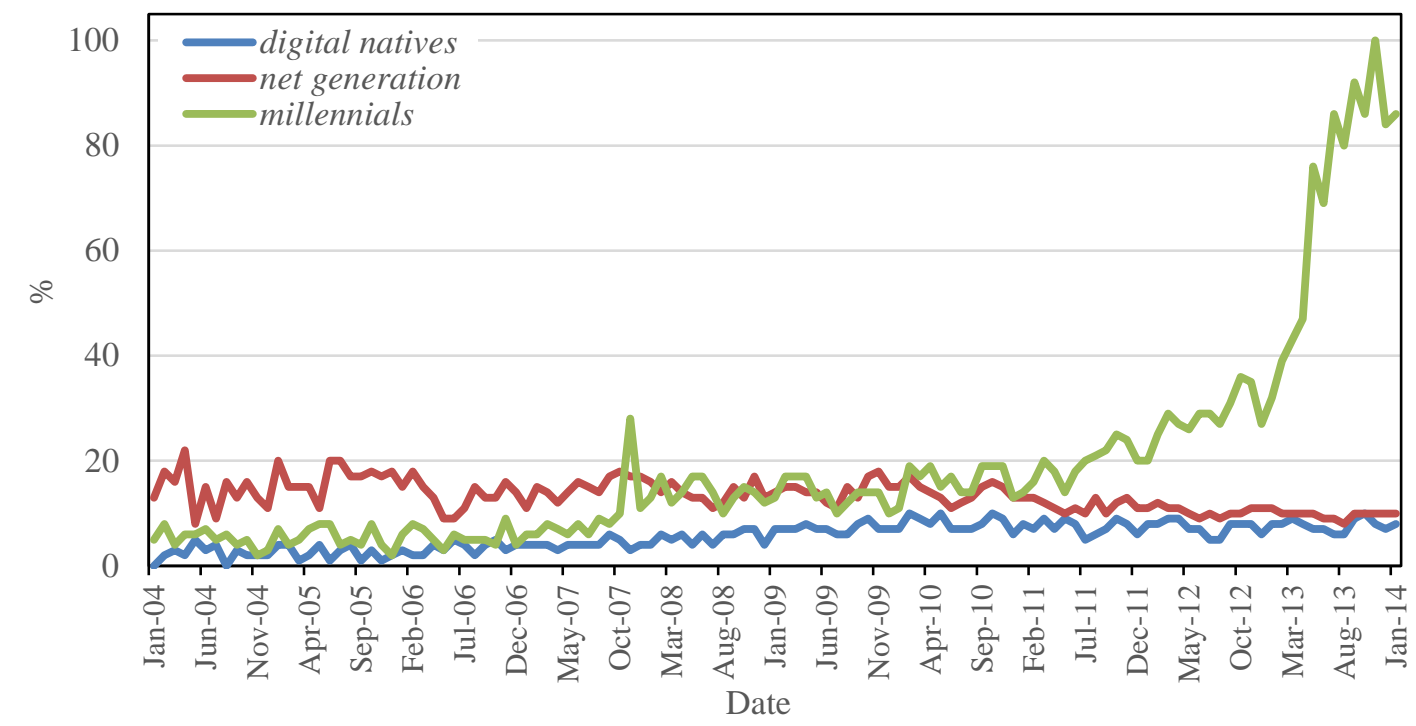

Figure 1. Google Trends data for relative interest in the search terms digital natives, net generation and millennials between January 2004 and January 2014 (source: Google Trends, September 2017)

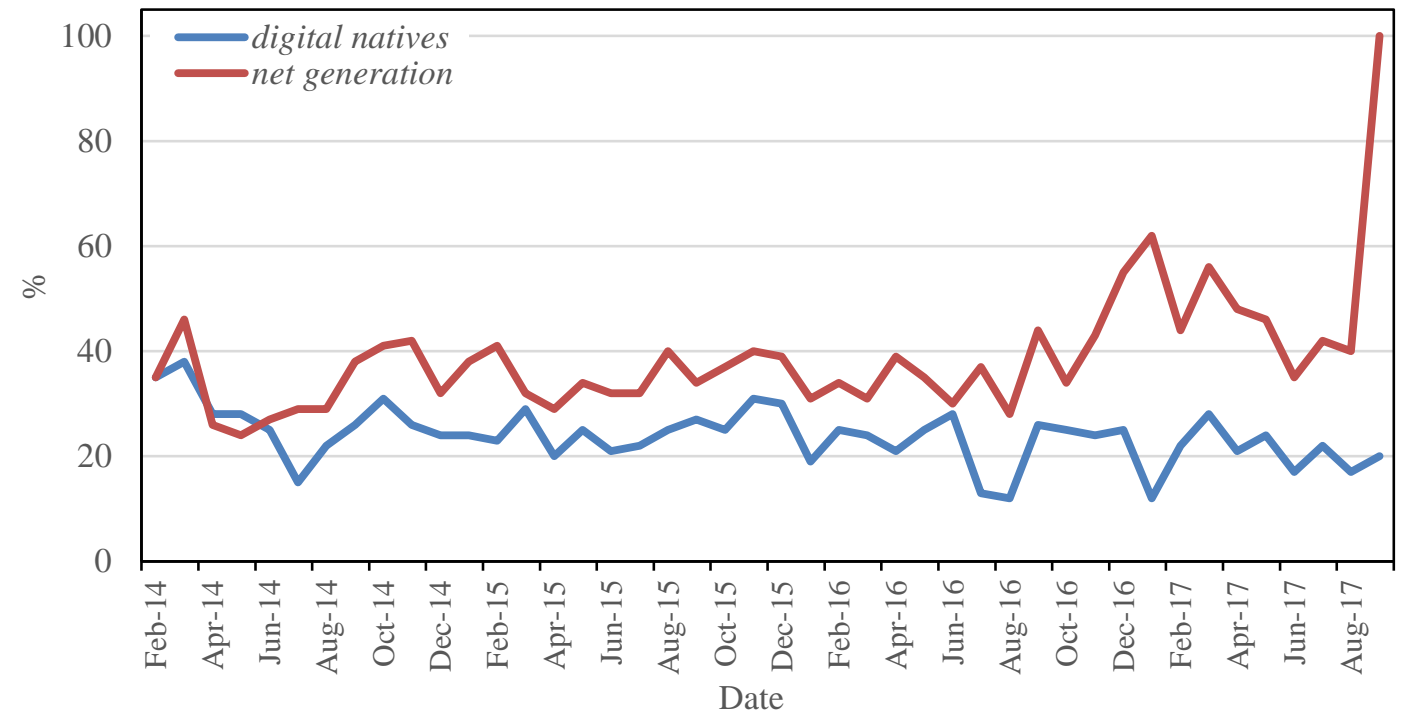

Figure 2. Google Trends data for relative interest in the search terms digital natives and net generation between February 2014 and September 2017 (source: Google Trends, September 2017) 


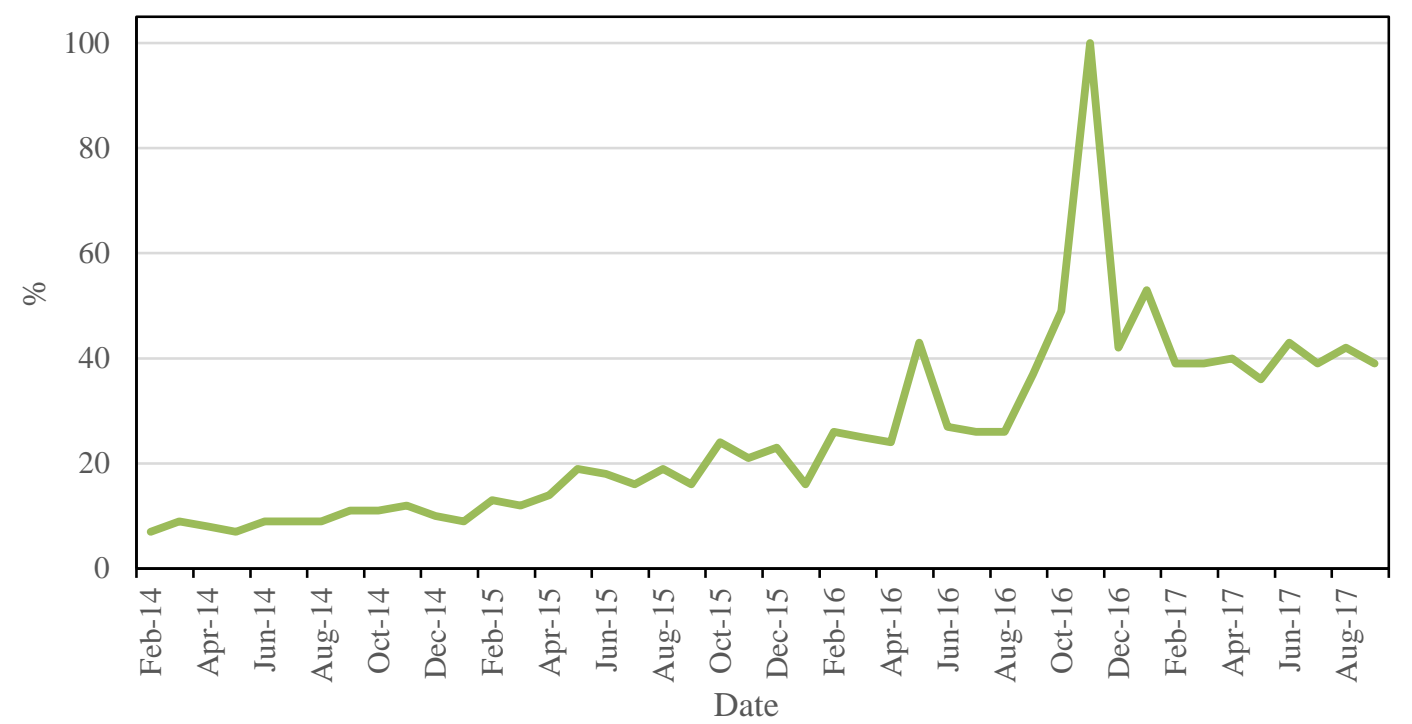

Figure 3. Google Trends data for relative interest in the search term millennials between February 2014 and September 2017 (source: Google Trends, September 2017)

Google Trends also provides some information on the level of interest in search terms and topics by geographical region. When viewed across the entire period for which data was available (January 2004 to September 2017; Figure 4), the Trends results reveal that searches involving digital natives were relatively common in North America (United States and Canada), Australia, the United Kingdom and western Europe and South Africa. Interest in net generation was again strong in North America and Australia, but less so in Europe and the United Kingdom. Interest in millennials was much more widespread, although heavily concentrated in the United States. These patterns appear to have been quite consistent over time as similar distributions were produced when the same queries were run for intermediate time intervals (e.g., 2004-2009, 2012-2017, 2016-2017). 


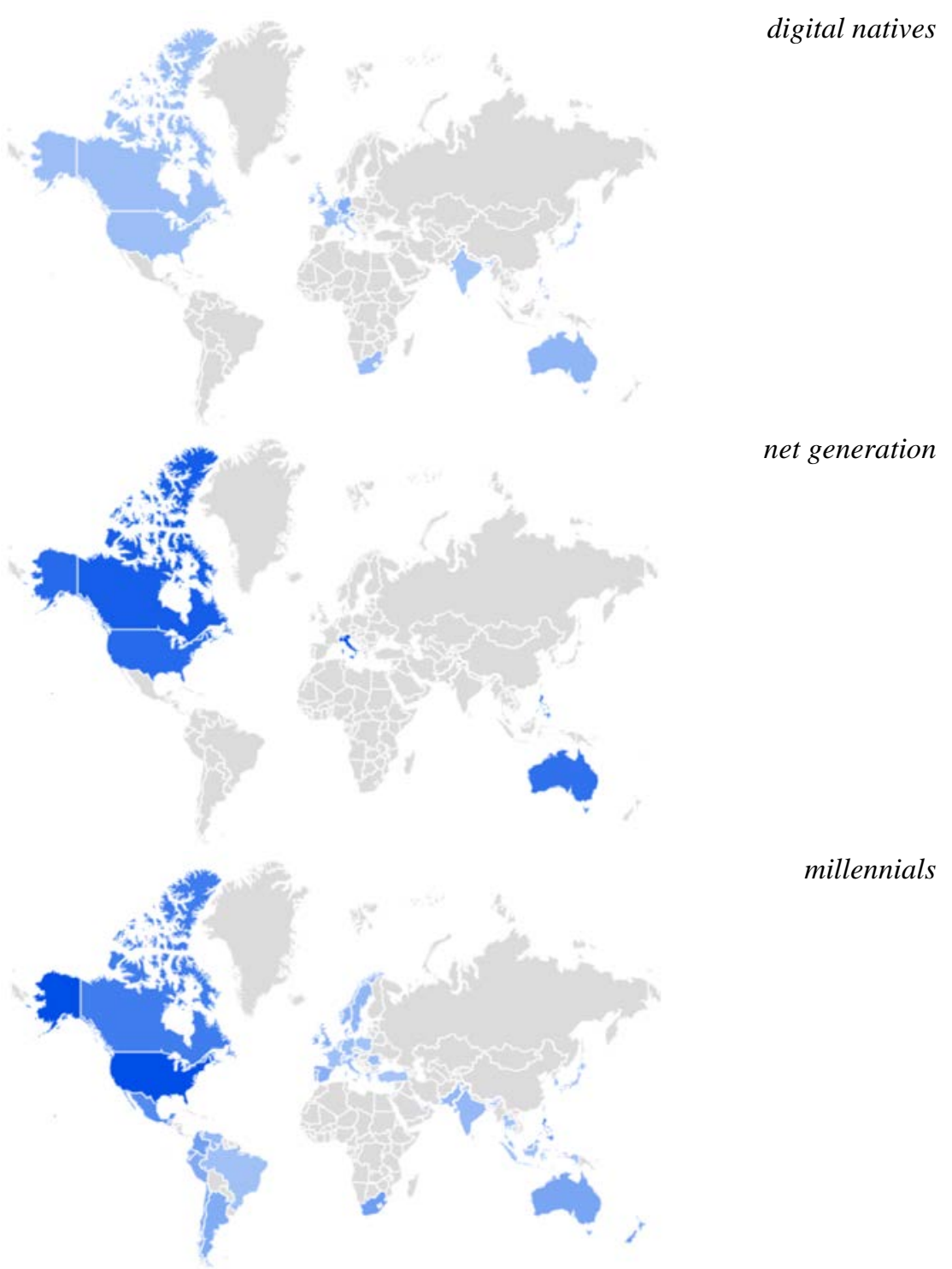

Figure 4. Google Trends data for relative interest in digital natives, net generation and millennials by geographical region, between January 2004 and September 2017 (source: Google Trends, September 2017)

\section{Assessing the number of general and academic articles, sites and pages related to digital natives, the net generation and millennials}

The availability of both general and academic resources related to the three main search terms was assessed by conducting simple keyword (or key-phrase) searches of these terms using the "Advanced Search" versions of Google's main search engine (https://www.google.com/advanced_search) and its Google Scholar search engine. Additional measures of their occurrence within resources that are potentially related to learning and teaching, technology generally and social media more specifically, were developed by conducting both types of search with and without the inclusion of supplementary search terms; these being either technology AND (education OR learning) or social media. The main search terms were entered in the "this exact word or phrase" field while the supplementary terms were entered as appropriate in either the "all of these words" or "any of these words" fields. All Google Scholar searches excluded citations and patents. 
All searches were conducted during September 2017 and provide estimates of the number of general or academic web pages, documents, articles and books indexed by Google containing the specified search terms at that time. The results of these searches are summarised in Table 1. However, it should be noted that repeating these searches may produce different results because of regular changes to Google's search algorithms.

Searches for millennials using Google produced more than 45 million results, 58 times the number of results for digital natives and 114 times that for net generation. Including the additional search terms technology and either education or learning reduced the number of results by around $50 \%$ for each of the main search terms. Including social media as a supplementary search term also produced around half the number of results for millennials and digital natives but reduced the results for net generation by around $80 \%$ (Table 1 ), indicating a much weaker link between the two terms.

The number of results for the same searches in Google Scholar were many times lower, by a factor of 12 for net generation, 20 for digital natives, and almost 1000 for millennials. The number of search results for the main search terms on their own was again highest for millennials although not by a large margin. Once the supplementary terms were included, searches involving the term digital natives returned the highest number of results for each comparison. Including the terms technology and either education or learning resulted in much smaller reductions in the number of results than for ordinary Google searches ( $15 \%$ for digital natives, $29 \%$ for net generation and $28 \%$ for millennials) indicating that academic use of all three terms has a relatively strong learning and teaching and/or educational technology focus. Again, the search term social media was least strongly associated with net generation, resulting in a $77 \%$ reduction in search results, versus $49 \%$ for digital natives and $62 \%$ for millennials (Table 1 ).

Table 1

Number of returned Google search results (source: Google, Google Scholar, September 2017) including the three main search terms (digital natives, net generation and millennials) with or without additional search terms ( $T$ = technology, $E=$ education, $L=$ learning, $S M=$ social media)

\begin{tabular}{llll}
\hline Search engine & Search term & Additional terms & No. of results \\
\hline Google Search & digital natives & none & 806,000 \\
& & T AND (E OR L) & 465,000 \\
& & SM & 432,000 \\
\cline { 2 - 4 } & net generation & none & 411,000 \\
& T AND (E OR L) & 191000 \\
& SM & 78700 \\
\cline { 2 - 4 } & millennials & none & $46,900,000$ \\
& & T AND (E OR L) & $20,400,000$ \\
& SM & $22,600,000$ \\
\cline { 2 - 4 } Google Scholar & none & 40,400 \\
& digital natives & T AND (E OR L) & 34,500 \\
& & SM & 20,700 \\
\cline { 2 - 4 } & none & 34,700 \\
& net generation & T AND (E OR L) & 24,700 \\
& & SM & 8040 \\
\cline { 2 - 3 } & millennials & T AND (E OR L) & 49,300 \\
& & SM & 25,600 \\
& & 18,600 \\
\hline
\end{tabular}




\section{Assessing the use of digital natives, net generation and millennials in an academic, learning and teaching context over time}

Academic mentions and citations of the three key search terms and primary sources

Use of the three key search terms within the academic literature was assessed by publication year for the period 1998 to 2016. Google Scholar's “Advanced Search” tool was used to conduct similar searches to those described in the previous section (primary plus supplementary search terms) for each year with the defined period. Annual citation frequencies of the three primary source articles were also recorded. Figure 5 presents search results data for the three primary search terms. Figure 6 presents these same data as a proportion of articles containing any of the three terms (source: Google Scholar, September 2017), and Figure 7 presents the number of citations for each of the three primary sources (Howe \& Strauss, 2000; Prensky, 2001a; Tapscott, 1998) over the same time frame.

Comparing the results of the search term and citations data reveals some clear trends. Overall academic use of the terms digital natives, net generation, and millennials has grown strongly from around 2005 onwards (Figure 5). As for the Google Trends data (Figure 1), this interest was initially focused on net generation, but proportional use in this term steadily declined as use of the term digital natives increased (Figures 5 and 6). Academic use of the term digital natives overtook net generation in 2008 and has continued to climb, albeit more slowly from around 2014. Academic use of the term millennials grew slowly until around 2013 at which point it increased sharply, similar to the (much larger) increase evident in the Google Trends data (Figures 1 and 5). Millennials passed digital natives as the most used of the three terms in 2015 (Figures 5 and 6). The citations data for the three primary sources reveals a somewhat different pattern, with a much larger and sustained increase in citations of Prensky's (2001a) article after 2006, peaking in 2014 (Figure 7). Interestingly, citations of Howe and Strauss' (2000) book have increased only marginally in the last few years despite the large recent increases in academic use of the term millennials. Although not included in Figure 6, the total citations for the three primary references (as of September 2017) were all very high - from around 4100 for Howe and Strauss (2000) and 5100 for Tapscott (1998) to a staggering 18,400 for Prensky (2001a).

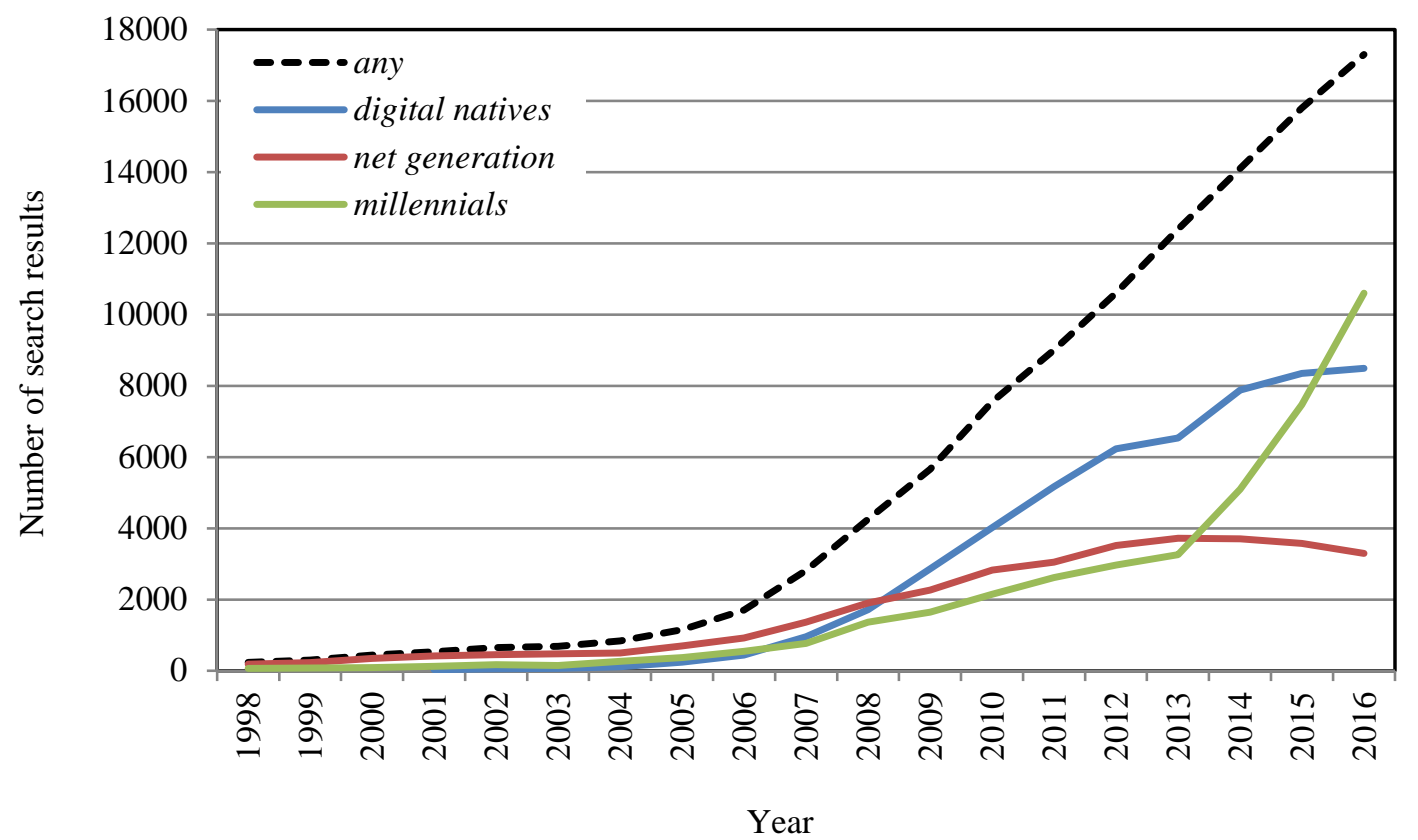

Figure 5. Number of returned Google Scholar search results for articles published between 1998 and 2016 that include the three main search terms (source: Google Scholar, September 2017) 


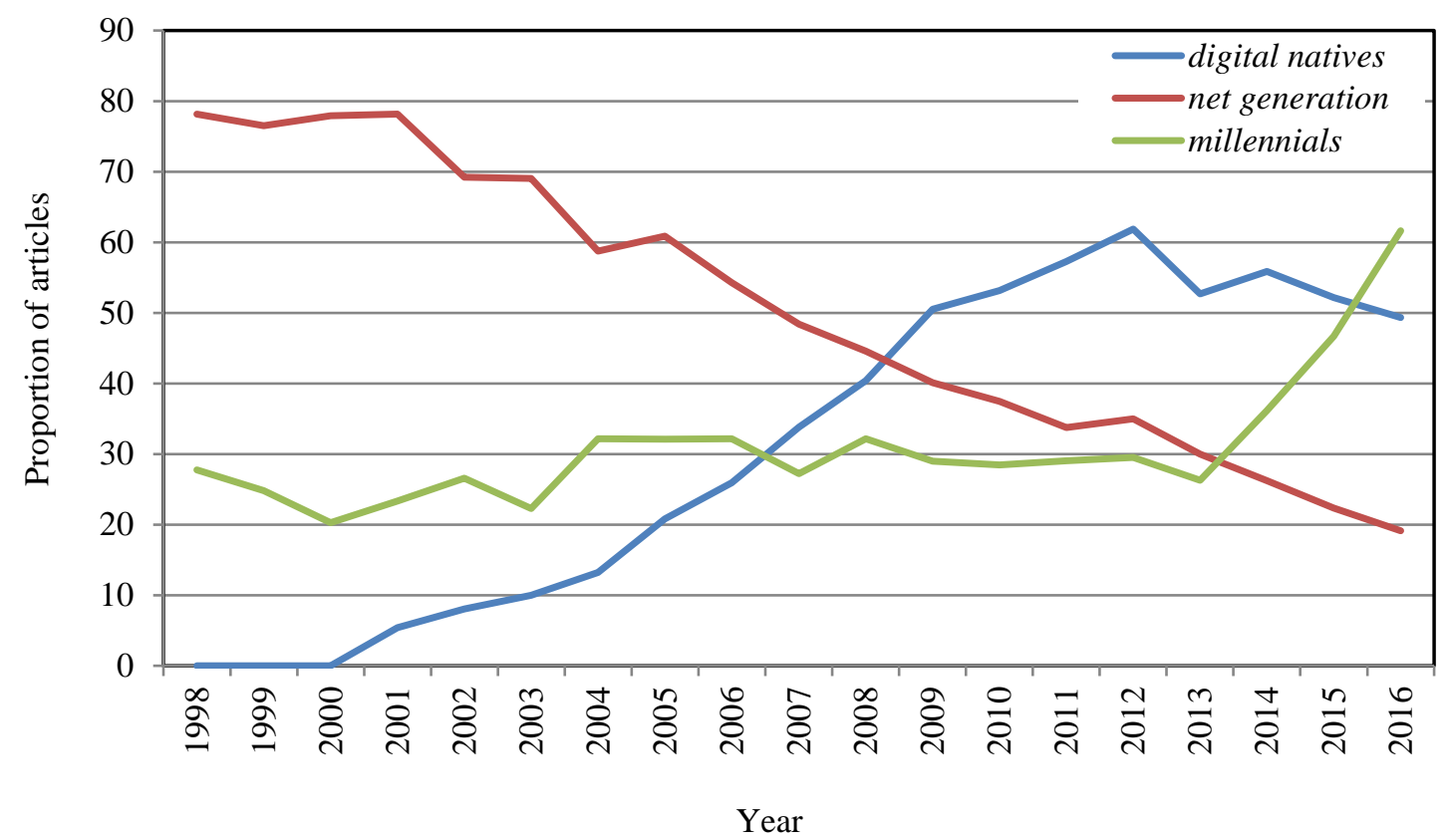

Figure 6. Number of articles published between 1998 and 2016 containing the three main search terms as a proportion of articles containing any these terms (source: Google Scholar, September 2017)

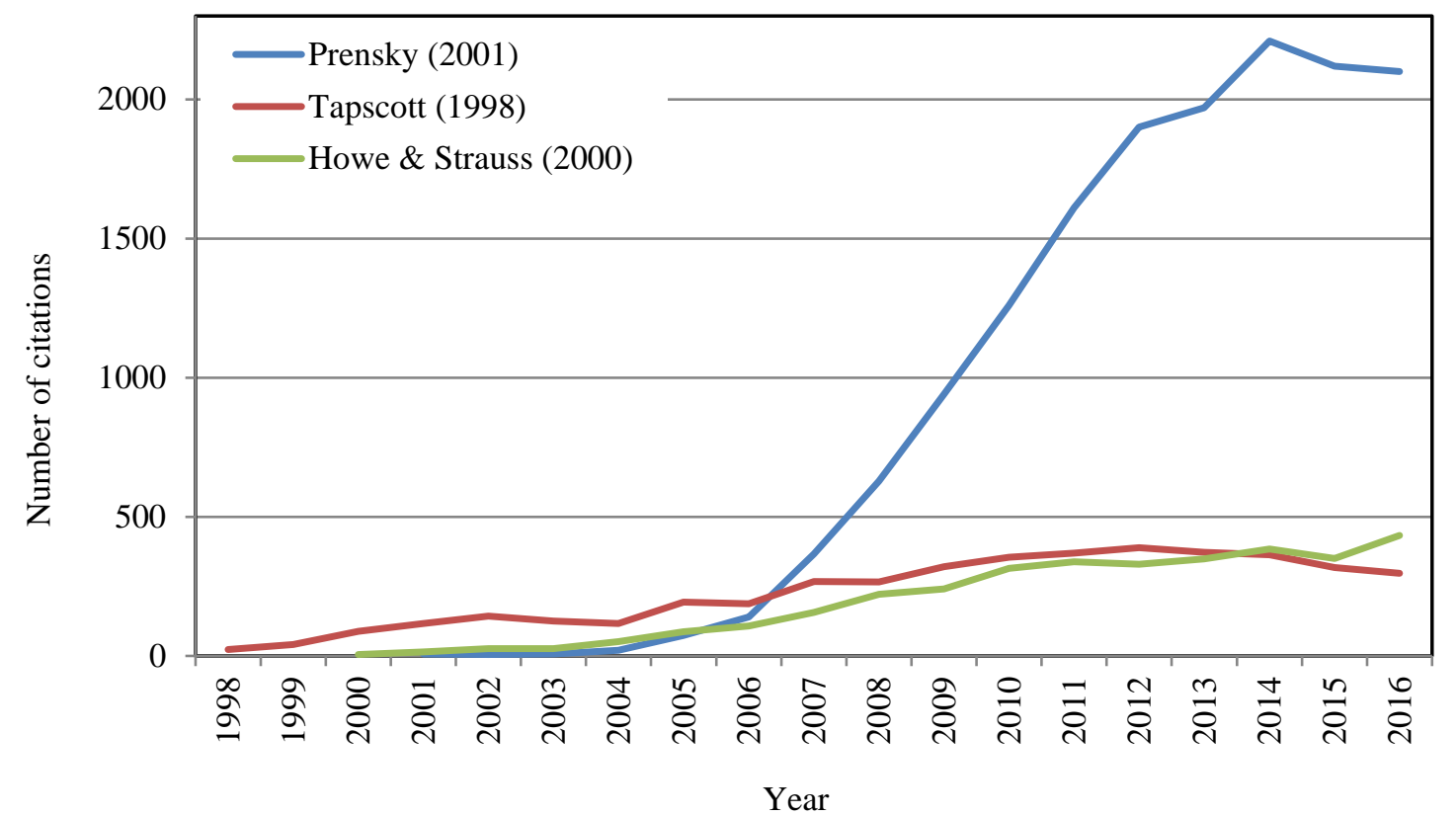

Figure 7. Annual citations for the three primary articles or publications on digital natives (Prensky, 2001a), the net generation (Tapscott, 1998) and millennials (Howe \& Strauss, 2000) (source: Google Scholar, September 2017) 
Context and academic citation of most highly cited secondary sources

The most highly cited secondary sources - that is, articles or books concerned primarily or largely with analysis or commentary of or surrounding digital natives, the net generation or millennials - were identified through an initial Google Scholar search and confirmed by searching and reading within the individual sources. Google Scholar citation numbers for each of these sources with total citations of 600 or more were then recorded for each year between their year of publication and 2016. The stance of the sources refers to whether the views expressed within the article or book were favourable to or at least generally consistent with the views put forward by the authors of one or more of the three primary sources (i.e., Howe \& Strauss, 2000; Prensky, 2001a; Tapscott, 1998).

The results of these analyses are presented in Table 2 and Figure 8. Table 2 includes the total number of citations (as of September 2017) of all the identified articles or books. Figure 8 presents the year-by-year citations of nine of the articles or books from three key publication years: 2005, 2008 and 2010.

Of the 17 identified works with more than 600 citations, seven articulated a moderately or strongly critical stance of the digital natives, net generation or millennials concepts. Five of the ten other works were authored by either Prensky (2005, 2009, 2010), Tapscott (2008) or Howe and Strauss (2007), so it is relatively unsurprising that they adopted a favourable stance. Three of the remaining five works were authored or coauthored by Oblinger (Oblinger, 2003; Oblinger \& Oblinger, 2005; Oblinger et al., 2005) and were published prior to the emergence of evidence or analysis antithetical to or critical of the digital natives, net generation or millennials concepts. All of the critical articles mentioned were published between 2008 and 2011, with Bennett et al.'s (2008) article being easily the most frequently cited.

Table 2

Most cited secondary articles or books about digital natives, the net generation or millennials as of September 2017. Right-hand column indicates where authors have adopted a favourable, critical or neutral stance in their analysis or arguments (source: Google Scholar, September 2017).

\begin{tabular}{llll}
\hline Author(s) & Year & Citations & Stance \\
\hline Tapscott & 2008 & 3078 & favourable \\
Bennett et al. & 2008 & 2749 & critical \\
Palfrey \& Gasser & 2008 & 2729 & favourable \\
Oblinger et al. & 2005 & 2410 & favourable \\
Lenhart, Purcell, Smith, \& Zickuhr & 2010 & 2391 & neutral \\
Oblinger & 2003 & 1447 & favourable \\
Kennedy, Judd et al. & 2008 & 1176 & critical \\
Oblinger \& Oblinger & 2005 & 1056 & favourable \\
Prensky & 2005 & 1014 & favourable \\
Hargittai & 2010 & 964 & critical \\
Prensky & 2010 & 996 & favourable \\
Prensky & 2009 & 657 & favourable \\
Howe \& Strauss & 2007 & 878 & favourable \\
Margaryan et al. & 2011 & 793 & critical \\
Jones et al. & 2010 & 719 & critical \\
Helsper \& Eynon & 2010 & 697 & critical \\
Selwyn & $2009 a$ & 647 & critical \\
\hline
\end{tabular}

Plotting citations of the most popular of these works by year reveals several patterns (Figure 8). Perhaps the most consistent one is that virtually all works show a peak in citations in about 2013, followed by an obvious decline. This is only partially consistent with the results for the previous section, where use of the term net generation and citations of Tapscott's (2008) book peaked and then gradually declined, while citations of Prensky's (2001a) paper remained strong over the same period (Figures 5 and 7). Of the three works published in 2005, Oblinger et al. (2005) is much more frequently cited than the other two. The three 2008 works by Bennett et al., Tapscott, and Palfrey and Gasser - with Bennett et al. (2008) taking a critical stance 
and the other two favourable ones - follow similar trajectories and citation rates, as do the two later (2010) publications - again, one critical (Hargittai, 2010) and one favourable (Prensky, 2010). There is, therefore, no obvious pattern of citation that clearly differentiates between favourable and critical works.

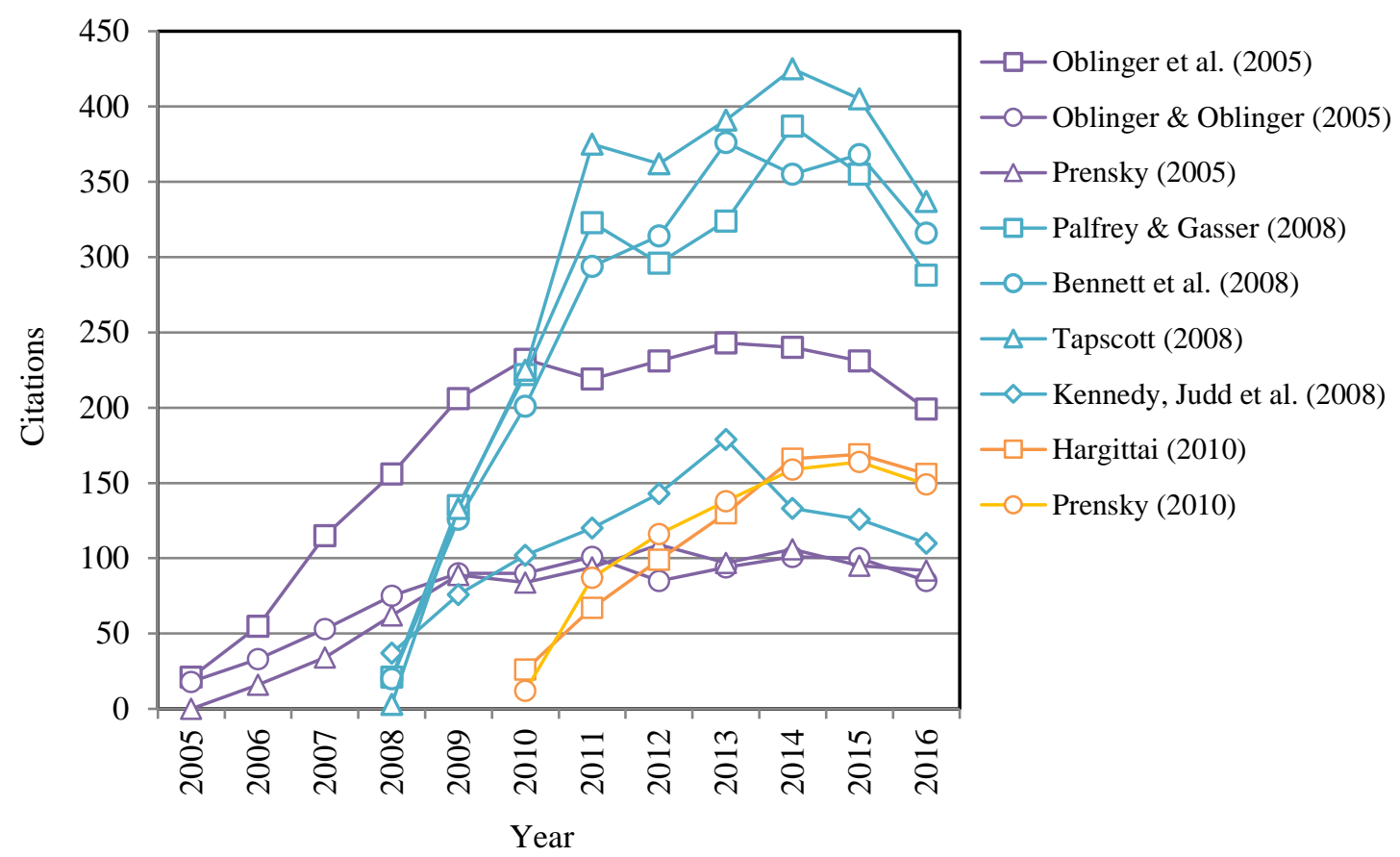

Figure 8. Annual citations for key secondary articles and publications on digital natives, the net generation or millennials (source: Google Scholar, September 2017)

Context of use of terms in leading educational technology journals

Use of the terms digital natives, net generation and millennials within a technology in education or learning context was further explored by locating and reviewing all articles containing one or more of these terms published within four leading educational technology journals (Computers \& Education - impact factor (IF) = 3.82; British Journal of Educational Technology - IF = 2.41; Journal of Computer Assisted Learning - IF = 1.36; Australasian Journal of Educational Technology - IF $=0.85$. The impact factors are derived from Thompson Reuters InCites ${ }^{\mathrm{TM}}$ Journal Citation Reports (InCites, 2016)). Again, using Google Scholar's “Advanced Search” tool, all articles published between 1998 and 2016 that contained at least one of these terms were identified for each of the four journals. All identified articles were then downloaded and searched to confirm the inclusion of the at least one of the three terms, and then if confirmed the article was searched and read more thoroughly to determine where and how the terms were reported within the article. Each article was scored based on the presence or absence of each term within (a) the title, abstract or body of the article and (b) the article's reference list. Context of use in this case refers to whether the use of the term or terms within the article implied or supported a generally critical, neutral or favourable application or interpretation of Prensky's (2001a), Tapscott's (1998) or Howe and Strauss's (2000) ideas. If the search terms were included only in an article's reference list, then the passages of text containing the relevant references were read to ascertain an actual or implied context of use. If this, or the use of the terms within the body of the paper more generally, was unclear, ambiguous or implied an unrelated context of use, then use of the term or terms was scored as “incidental."

In total, 444 articles across the four journals were confirmed as meeting the search criteria and were assessed by the author (Computers \& Education, $n=204$; British Journal of Educational Technology, $n=96$; 
Australasian Journal of Educational Technology, $n=95$; Journal of Computer Assisted Learning, $n=49$ ). A full list of these articles is available on request. All assessed articles were published between 2004 and 2016. The results of the search and assessment are presented in Figures 9 and 10. Figure 9 documents the number of articles that include one or more of the three primary search terms by year over time, while Figure 10 presents the relative proportions of articles in which the terms are used in a critical, neutral, favourable or incidental context.

Use of the three primary terms within the four educational technology journals reveals a marked difference to the academic literature more generally. Whereas overall academic use of the terms continues to increase (Figure 5), use within the four educational technology journals has been in clear decline since 2011, reflecting steady declines in the use of the two more common terms, digital natives and net generation (Figure 9). This decline occurs earlier and is more pronounced than in the general academic literature and is not offset by any increase in the use of the term millennials, which remains quite low throughout the study period (Figure 9).

The context of use of the terms within the four journals is somewhat variable (Figure 10). If we discount the period 2004 to 2007, where the total number of articles containing any of the three terms in any one year was fewer than 10, then the proportion of critical articles peaks in 2010, two years after the publication of Bennett et al.'s (2008) article, and then remains comparatively strong (outnumbering neutral and favourable articles) in four of the five years until 2015. It is then much lower in 2016. The proportion of favourable articles is highest in 2009, after which it reduces and stabilises at around 20\% (Figure 9). The proportion of neutral articles is also relatively stable (20\%-25\%), except for 2016 when it accounts for almost $40 \%$ of all articles. Incidental mentions account for approximately 20\% of mentions between 2009 and 2014, before increasing to around $40 \%$ in 2015 and 2016. The majority of these were attributable to citation of articles within these publications that included one of the three terms in their title but the context of the citation was either not or only tangentially related to arguments or evidence associated with digital natives, the net generation or millennials.

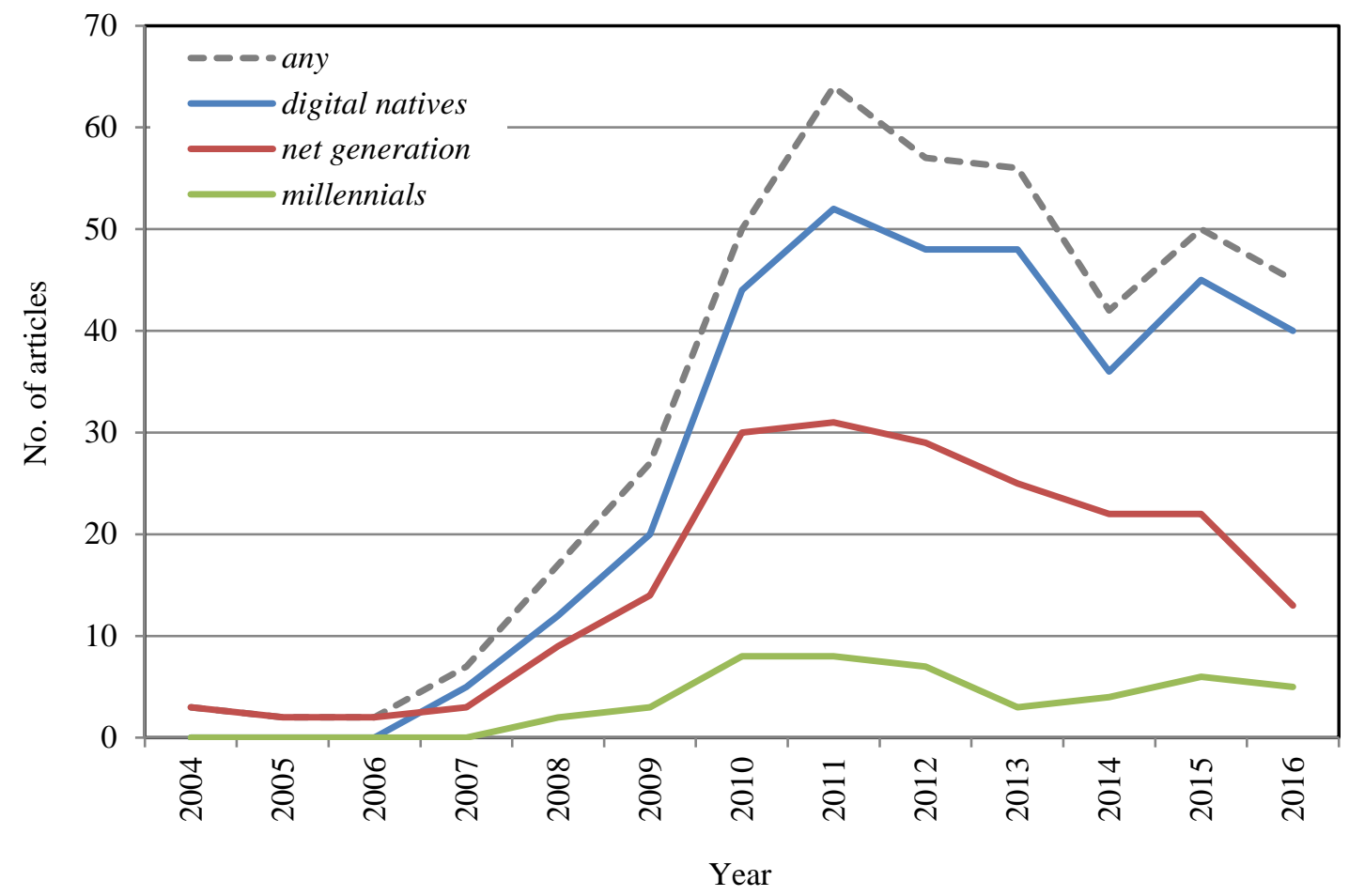

Figure 9. Number of articles per year published within the four target journals and containing one or more of the terms digital natives, net generation or millennials 


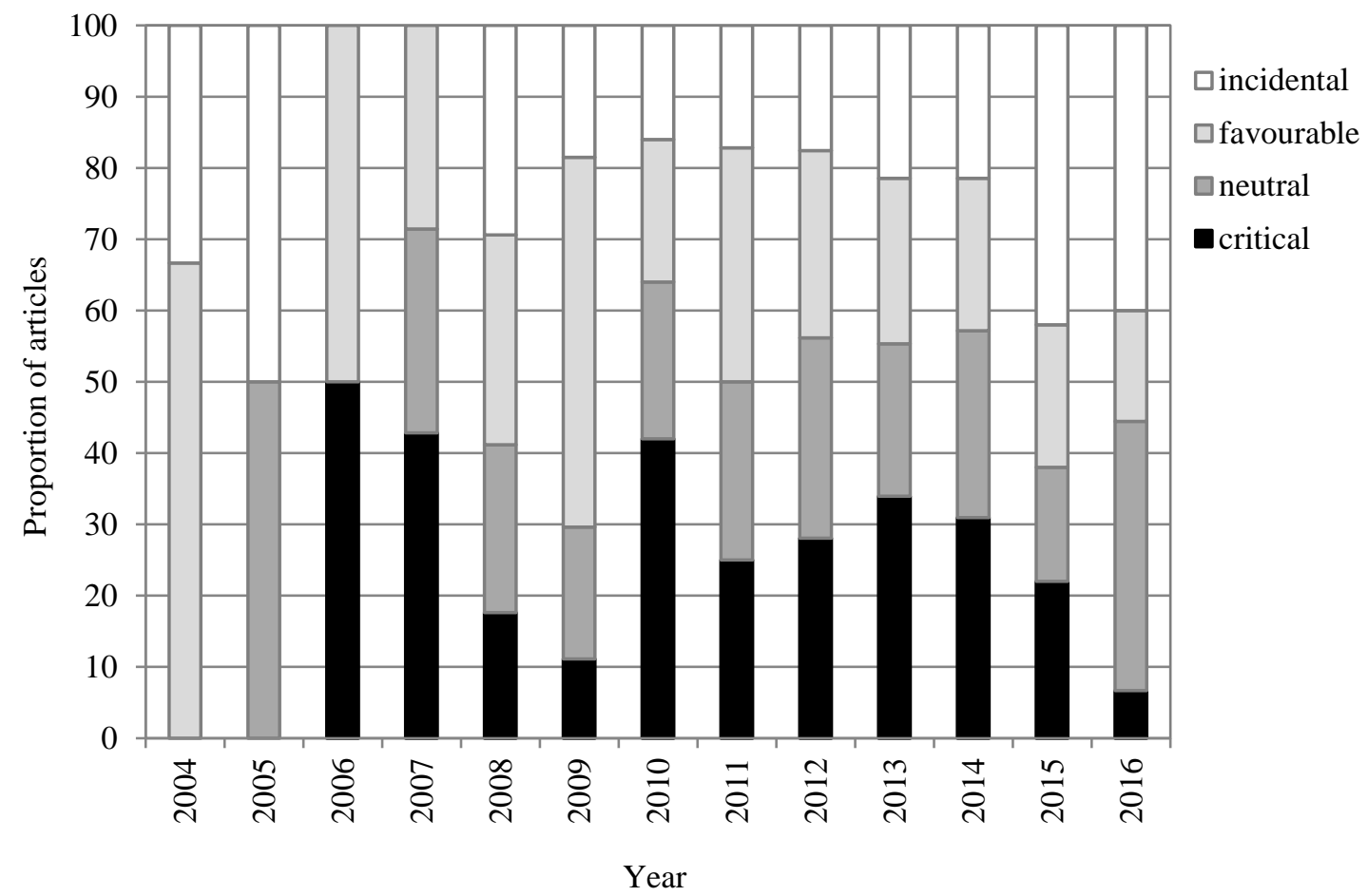

Figure 10. Proportion of matching articles (see Figure 9) adopting a favourable, neutral or critical stance

\section{Discussion}

\section{Is the digital natives concept still relevant?}

This seems to depend on whom you are asking and how broad your definition of digital natives is. If your definition includes digital natives, the net generation, and millennials, then among the general population the answer is a clear yes. This is evidenced by a marked expansion of search activity since 2012 driven almost entirely by increased interest in millennials (Figures 1-3), on top of reasonably steady levels of interest in the other two terms. If you're assessing academic relevance, then the answer is also yes, with steady year-to-year increases in the number of academic articles including one or more of the search terms between 2006 and 2016 (Figure 5). If we unpick these academic results a little, then the more recent increases are being driven by strong interest in millennials (Figures 5 and 6), against a gradual decline in interest in the net generation (since 2013) and at least a levelling off of interest in digital natives (since 2015). Citations of Prensky's (2001a) original paper on digital natives, which is easily the most cited of any articles or books dealing with the digital natives, the net generation, or millennials, have also remained strong - although there has been only minor annual growth since 2012. The picture within the educational technology literature is quite different, however. Here there has been a marked decline in the use of each of the terms, including millennials, since 2011 (Figure 9).

This decline is perhaps the strongest sign that these terms, and some of the key attributes usually associated with them - for example, universally high digital literacy, enhanced multitasking ability - are losing favour within the educational technology community. There is no clear evidence of either an increase in the proportion of articles that are critical of Prensky's or Tapscott's views or a decrease in those that are supportive (Figure 9), although neither would necessary follow from reduced overall usage. If there has been a change in the contextual use of these terms, then it is only within the last couple of years (since 2015) when 
most mentions either invoked a neutral stance or were primarily incidental. This could reflect a shift away from the concepts underpinning the terms, as well as use of the terms more generally.

In interpreting the various search and publication results, we also need to consider what age ranges each of the three terms apply to. Tapscott (1998) originally defined the net generation as being born between 1977 and 1997, placing (in 2017) the youngest at 20 and the oldest at 40. Prensky didn't mention a specific start or end date for the digital natives, simply referring to "today's students - K-12 through college" (Prensky 2001a, p. 1 ) as being the first to grow up surrounded by digital technologies. However, assuming a start date of around 1980 (i.e., college-aged students when Prensky's article was published in 2001), that would put the oldest digital natives in their late thirties while potentially including everyone born since. Howe and Strauss (2007) put the millennials' start date slightly later - 1982 - and an end date of around 2004, which places the oldest in their mid-thirties and the youngest just entering their teens. All three ranges overlap with the ages of current (2017) student cohorts, suggesting that these terms - with the possible exception of net generation might remain in use for some years to come. Such use would, however, be at odds with what we know about recent, current, and presumably future students' technological skills, preferences and needs, particularly as they relate to learning and teaching. Educational technologists appear to have taken the evidence on board, as shown by the continuing decline in the use of the terms within educational technology journals (Figure 9). However, given the continuing interest in and use of the terms within the wider academic community, it appears that this same evidence continues to be ignored by or perhaps remains unfamiliar to many of our academic colleagues.

Although the context of the use of the three terms within the wider academic and general communities wasn't explicitly examined, there is a sense that much of this use is within a generational rather than specifically technological or educational context. If this is the case, and if generational constructs are indeed useful or necessary for differentiating between past, recent or current students, then more neutral terms like generation $Y / Z$ would seem to be more apt. These terms still invoke stereotypes but these are much less strongly associated with learning, teaching and technology than either digital natives or the net generation. Millennials is a slightly different use case. Although its original context of use was similar to that for digital natives and net generation, in the United States in particular it is often used as a catch-all term for the post $\mathrm{X}$ (i.e., $\mathrm{Y}$ and Z) generations. Given our tendency to adopt US popular cultural trends, it seems almost inevitable that we will follow suit.

\section{Moral panic averted?}

When Bennett et al. (2008) wrote about a present or looming moral panic regarding how we should approach and teach digital natives within our universities, the level of interest in digital natives, the net generation and millennials was well below where it sits now - among the general population (by a factor of 20 or more based on Google Trends data), the general academic population (by a factor of around 4 based on Google Scholar search data) and the educational technology community (by a factor of 2.5 based on Google Scholar search data within the four targeted educational technology journals). Arguably however, the level of concern about the role and influence of technology in education, and the degree to which it should be shaped by students' perceived preferences or needs, has fallen rather than risen since then. There are a few possible explanations for this.

One is that Bennett et al.'s (2008) characterisation of this concern as a moral panic overstated the perceived problem. We should recall, however, that well before the emergence of digital natives, the net generation and millennials - and the rise of the Internet even - Papert (1990) cautioned against the rise of technocentrism (a form of technological determinism) in education - where attention is focused on the technology rather than the underlying educational principles or activities it is intended to support. Prensky's (2001a) and Tapscott's (1998) ideas are clearly deterministic, and both advocated major change to the way we teach our students, with little supporting evidence. Given that, the level of scrutiny and caution advocated by Bennett et al. (2008) and subsequent authors, who warned that examples of technological determinism were common within the educational technology literature (e.g., Bennett \& Maton, 2010; Oliver, 2011, 2013; Selwyn, 2012), was and appears to remain warranted. 
Another is that a moral panic of sorts existed, but was neutralised as evidence contrary to the ideas of Prensky, Tapscott and others emerged and was accepted. This is perhaps more likely within our local context (i.e., Australian universities), where interest in digital natives and the net generation was and has remained strong (see Figure 5), and where some of the earliest and most frequently cited research critical of Prensky's ideas was developed (e.g., Bennett et al., 2008; Kennedy, Judd et al., 2008). In the case of Kennedy and colleagues, dissemination of their findings was supported by the government-funded Office for Learning and Teaching, ensuring it had wide reach within the Australian higher education sector. The same may be true in the United Kingdom, where a number of critical articles were published between 2009 and 2011 (e.g., Helsper \& Enyon, 2010; Jones et al., 2010; Margaryan et al., 2011; Selwyn, 2009a). However, it seems less likely in the North American context, where the digital natives, net generation and millennials ideas originated and remain strong (see Figure 4). Early advocacy also tended to be stronger there (e.g., Oblinger et al., 2005), and although several large empirical studies of students' use of technology were undertaken - most notably EDUCAUSE's "ECAR Study of Undergraduate Students and Information Technology" series (https://library.educause.edu/ ) - among US-based researchers, perhaps only Hargittai (2010) openly disputed key assertions about the technical skills and preferences of digital natives, the net generation or millennials.

A third explanation is that our level of concern has gradually dissipated as more and more complex learning technologies have been progressively adopted by institutions, departments and individual educators. Although there is no direct evidence to support this, the size and scope of technology use within the higher education sector appears to have grown markedly in recent years, based on sources such as New Media Consortium's annual Horizon Reports (https://www.nmc.org/nmc-horizon/) and ECAR's "Study of undergraduate students and information technology" series (https://ibrary.educause.edu/). Some obvious examples of major technology-related changes at the institutional level include routine support for mobile and personal devices (which are now more or less ubiquitous, for students and staff alike), a shift towards blended and fully online learning approaches, and the substantial replacement of physical library resources with online ones.

To what degree these changes have been driven by the perceived technology-based learning needs and preferences of students, versus primarily administrative or pedagogical imperatives, remains unclear. However, subjects or courses that make limited use of technology to support their delivery are now the exception rather than the rule. What is perhaps clearer is that technologies most used and favoured by young adults (and students) aren't necessarily immediately suited or relevant to formal educational settings, and that their level and type of use may be quite different in and outside of school (Bennett et al., 2008). This includes popular social media tools and services, like Facebook, Instagram and Twitter, which despite their potential academic affordances and numerous educational trials, have not been widely adopted by teaching staff (Hew, 2011). Again, the suggestion here is that social media are a key element of students' personal social identity, and while they may use them to support their own learning, they are less willing for them to be co-opted as formal learning and teaching tools (Madge et al., 2009; Mok, 2012).

Bennett and Maton argued strongly for a "more nuanced understanding of students' technology experiences" (Bennett \& Maton 2010, p. 321). This seems to be occurring, driven at least in part by advances in learning analytics, which according to Google Trends, has from around 2012 onwards experienced a steady increase in interest. Recent learning analytics-based studies appear to complement and confirm the sort of data and findings that emerged from the earlier survey-based studies of Kennedy, Judd et al. (2008) and others (e.g., Jones et al., 2010). For example, studies of lecture capture use (Phillips, Maor, Preston, \& Cumming-Potvin, 2012), MOOC participation (Coffrin, Corrin, de Barba, \& Kennedy, 2014), and learning resource use (Judd \& Elliott, 2017) each reveal patterns of variable levels of technology adoption, use and engagement that are inconsistent with the digital native, net generation and millennials stereotypes. The challenge for educators and institutions is to interpret these patterns and apply the data behind them to eventually support more personalised and effective technology-enhanced learning activities and environments (Gunn, 2014; Kennedy et al., 2014). 


\section{The rise and rise of the millennials}

Perhaps the most unexpected finding of the analysis of the Google Trends and Google and Google Scholar search data (Figures 1-5, Table 1) is in the relatively recent explosion of interest in millennials. As mentioned above, the suggestion here is that "millennials" has become the default label for all post-X generations, easily outstripping (since 2014, according to Google Trends) interest in generations Y and/or Z. While most of this interest is likely to be unrelated to technology use and learning, an association between the two clearly remains, both for general and academic search results (Table 1). The start of the main increase in interest in millennials dates from around mid-2012 (see Figure 1), and conducting a date constrained standard Google search (available via the "Search Tools" button on any Google search results page) around that time reveals the publication of series of popular articles on millennials in leading US magazines (e.g., Schawbel, 2013; Stein, 2013; Twenge, 2012). Whether these and subsequent articles drove this increase or were merely a response to it is unclear. Either way, the millennials undoubtedly have our attention and now represent the largest group by age in both the United States (Fry, 2016) and Australia (Australian Bureau of Statistics, 2017). So, while concern over how we are "educating the net generation" may have dissipated along with many of the original claims about the digital natives' abilities and preferences, millennials, including how they utilise technology, and how this use influences their learning and our teaching of them, are likely to capture our attention for some time to come.

\section{Conclusions}

Technology is a key part of students' personal and social lives and plays a central role in the delivery of teaching and learning within our universities. Ownership of smartphones and personal mobile devices is virtually universal and learning management systems support and increasing array of learning and teaching and activities and administrative tasks. Within this context, it is perhaps unsurprising that the digital natives/net generation/millennials stereotype continues to resonate with many academics. There is, however, still little evidence to support many of the key claims made by Prensky and like-minded commentators. The criticisms, best summarised by Bennett and colleagues (Bennett \& Maton, 2010; Bennett et al., 2008), that students' technological preferences and proficiencies are diverse, not uniform, and that these preferences and proficiencies do not lead to fundamental changes in the way that they learn or should be taught, still hold and appear to be supported by emerging analytics data. Although our influence over what the public believes about digital natives or the net generation is likely to remain limited, there seems to be little or no value in continuing to use these terms to refer to students or our teaching of them. That we can realistically restrict or avoid use of the term millennials seems unlikely as it is increasingly being used to refer to anyone born after generation $\mathrm{X}$.

\section{References}

Ashton, J., \& Newman, L. (2006). An unfinished symphony: 21st century teacher education using knowledge creating heutagogies. British Journal of Educational Technology, 37(6), 825-840. https://doi.org/10.1111/j.1467-8535.2006.00662.x

Australian Bureau of Statistics. (2017). Population by age and sex, regions of Australia, 2016. Retrieved from http://www.abs.gov.au/ausstats/abs@.nsf/0/151AA7593B394934CA2573210018DA4A

Becker, M. W., Alzahabi, R., \& Hopwood, C. J. (2013). Media multitasking is associated with symptoms of depression and social anxiety. Cyberpsychology, Behaviour and Social Networking, 16(2), 132- 135. https://doi.org/10.1089/cyber.2012.0291

Bennett, S., \& Maton, K. (2010). Beyond the 'digital natives' debate: Towards a more nuanced understanding of students' technology experiences. Journal of Computer Assisted Learning, 26(5), 321331. https://doi.org/10.1089/cyber.2012.0291

Bennett, S., Maton, K., \& Kervin, L. (2008). The 'digital natives’ debate: A critical review of the evidence. British Journal of Educational Technology, 39(5), 775-786. https://doi.org/10.1111/j.14678535.2007.00793.x 
Catalano A. 2013. Patterns of graduate students’ information seeking behavior: A meta-synthesis of the literature. Journal of Documentation, 69(2), 243-274. https://doi.org/10.1108/00220411311300066

Coffrin, C., Corrin, L., de Barba, P., \& Kennedy, G. (2014). Visualizing patterns of student engagement and performance in MOOCs. In M. Pistilli (Ed.), Proceedings of the Fourth International Conference on Learning Analytics and Knowledge (pp. 83-92). New York, NY: ACM. https://doi.org/10.1145/2567574.2567586

Ding, F., \& Stapleton, P. (2015). Self-emergent peer support using online social networking during crossborder transition. Australasian Journal of Educational Technology, 31(6), 671684. https://doi.org/10.14742/ajet.2305

Dux, P. E., Tombu, M. N., Harrison, S., Rogers, B. P., Tong, F., \& Marois, R. (2009). Training improves multitasking performance by increasing the speed of information processing in human prefrontal cortex. Neuron, 16(1), 127-138. https://doi.org/10.1016/j.neuron.2009.06.005

Ellison, N. B., Steinfield, C., \& Lampe, C. (2007). The benefit of Facebook “friends”: Social capital and students' use of online social networks. Journal of Computer-Mediated Communication, 12(4), 11431168. https://doi.org/10.1111/j.1083-6101.2007.00367.x

Ellison, N. B., Steinfield, C., \& Lampe, C. (2008). Social capital, self-esteem, and use of online social network sites: A longitudinal analysis. Journal of Applied Developmental Psychology, 29(6), 434-445. https://doi.org/10.1016/j.appdev.2008.07.002

Fry, R. (2016). Millennials overtake baby boomers as America’s largest generation. Washington, DC: Pew Research Center. Retrieved from http://www.pewresearch.org/fact-tank/2016/04/25/millennials-overtakebaby-boomers/

Gray, K., Annabell, L., \& Kennedy, G. (2010). Medical students’ use of Facebook to support learning: Insights from four case studies. Medical Teacher, 32(12), 971-976. http://doi.org/10.3109/0142159X.2010.497826

Gunn, C. (2014). Defining an agenda for learning analytics. In B. Hegarty, J. McDonald, \& S.-K. Loke (Eds.), Rhetoric and reality: Critical perspectives on educational technology. Proceedings ascilite Dunedin 2014 (pp. 683-687). Retrieved from http://ascilite.org/conferences/dunedin2014/files/concisepapers/257Gunn.pdf

Hamilton, D. L., \& Rose, T. L. (1980). Illusory correlation and the maintenance of stereotypic beliefs. Journal of Personality and Social Psychology, 39(5), 832-845. https://doi.org/10.1037/0022-3514.39.5.832

Hargittai, E. (2010). Digital na(t)ives? Variation in internet skills and uses among members of the "net generation”. Sociological inquiry, 80(1), 92-113. https://doi.org/10.1111/j.1475-682X.2009.00317.x

Hayes, M., van Stolk-Cooke, K., \& Muench, F. (2015). Understanding Facebook use and the psychological effects of use across generations. Computers in Human Behavior, 49, 507-511. https://doi.org/10.1016/j.chb.2015.03.040

Helsper, E. J., \& Eynon, R. (2010). Digital natives: where is the evidence? British Educational Research Journal, 36(3), 503-520. https://doi.org/10.1080/01411920902989227

Hew, K. F. (2011). Students' and teachers’ use of Facebook. Computers in Human Behavior, 27(2), 662-676. https://doi.org/10.1016/j.chb.2010.11.020

Howe, N., \& Strauss, W. (2000). Millennials rising: The next great generation. New York, NY: Vintage.

Howe, N., \& Strauss, W. (2007). Millennials go to college (2nd ed). Great Falls, VA: LifeCourse Associates.

InCites. (2016). Thompson Reuters InCites Journal Citation Reports. Retrieved from https://jcr.incites.thomsonreuters.com/

Ivala, E., \& Gachago, D. (2012). Social media for enhancing student engagement: The use of Facebook and blogs at a university of technology. South African Journal of Higher Education, 26(1), 152-167. http://hdl.handle.net/10520/EJC123970

Jones, C., Ramanau, R., Cross, S., \& Healing, G. (2010). Net generation or digital natives: Is there a distinct new generation entering university? Computers \& Education, 54(3), 722-732. https://doi.org/10.1016/j.compedu.2009.09.022

Judd, T. (2015). Task selection, task switching and multitasking during computer-based independent study. Australasian Journal of Educational Technology, 31(2), 193-207. https://doi.org/10.14742/ajet.1992

Judd, T., \& Elliott, K. (2017). Selection and use of online learning resources by first-year medical students: Cross-sectional study. Journal of Medical Internet Research, Medical Education, 3(2), e17. https://doi.org/10.2196/mededu.7382 
Judd, T., \& Kennedy, G. (2011). Expediency-based practice? Medical students’ reliance on Google and Wikipedia for biomedical inquiries. British Journal of Educational Technology, 42(2), 351-360. https://doi.org/10.1111/j.1467-8535.2009.01019.x

Junco, R. (2012). Too much face and not enough books: The relationship between multiple indices of Facebook use and academic performance. Computers in Human Behavior, 28(1), 187-198. https://doi.org/10.1016/j.chb.2011.08.026

Karpinski, A. C., Kirschner, P. A., Ozer, I., Mellott, J. A., \& Ochwo, P. (2013). An exploration of social networking site user, multitasking, and academic performance among United States and European university students. Computers in Human Behavior, 29(3), 1182-1192. https://doi.org/10.1016/j.chb.2012.10.011

Katai, Z. (2015). The challenge of promoting algorithmic thinking of both sciences-and humanities-oriented learners. Journal of Computer Assisted Learning, 31(4), 287-299. https://doi.org/10.1111/jcal.12070

Kennedy, G., Corrin, L., Lockyer, L., Dawson, S., Williams, D., Mulder, R., Khamis, S., \& Copeland, S. (2014). Completing the loop: Returning learning analytics to teachers. In B. Hegarty, J. McDonald, \& S.K. Loke (Eds.), Rhetoric and reality: Critical perspectives on educational technology. Proceedings ascilite, Dunedin 2014 (pp. 436-440). Retrieved from http://www.ascilite.org/conferences/dunedin2014/files/concisepapers/76-Kennedy.pdf

Kennedy, G., Dalgarno, B., Bennett, S., Judd, T., Gray, K. \& Chang, R. (2008). Immigrants and natives: Investigating differences between staff and students' use of technology. In Hello! Where are you in the landscape of educational technology? Proceedings ascilite, Melbourne 2008 (pp. 484-492). Retrieved from http://www.ascilite.org/conferences/melbourne08/procs/kennedy.pdf

Kennedy, G., Dalgarno, B., Gray, K., Judd, T., Waycott, J., Bennett, S. J., Maton, K. A., Krause, K., Bishop, A., Chang, R. \& Churchwood, A. (2007). The Net Generation are not big users of Web 2.0 technologies: Preliminary findings. In ICT: Providing choices for learners and learning. Proceedings ascilite, Singapore 2007 (pp. 517-525). Retrieved from http://www.ascilite.org/conferences/singapore07/procs/kennedy.pdf

Kennedy, G., Judd, T., Dalgarno, B., \& Waycott, J. (2010). Beyond natives and immigrants: exploring types of net generation students. Journal of Computer Assisted Learning, 26(5), 332-343. https://doi.org/10.1111/j.1365-2729.2010.00371.x

Kennedy, G., Krause, K., Judd, T., Churchward, A., \& Gray, K. (2006). First year students' experiences with technology: Are they really digital natives? Melbourne: University of Melbourne. Retrieved from https://www.griffith.edu.au/_data/assets/pdf file/0008/39266/NativesReport.pdf

Kennedy, G. E., Judd, T. S., Churchward, A., Gray, K., \& Krause, K. L. (2008). First year students’ experiences with technology: Are they really digital natives. Australasian Journal of Educational Technology, 24(1), 108-122. https://doi.org/10.14742/ajet.1233

Kirschner, P. A., \& Karpinski, A. C. (2010). Facebook and academic performance. Computers in Human Behavior, 26(6), 1237-1245. https://doi.org/10.1016/j.chb.2010.03.024

Koutropoulos, A. (2011). Digital natives: Ten years after. Journal of Online Learning and Teaching, 7(4), 525-538. Retrieved from http://jolt.merlot.org/vol7no4/koutropoulos_1211.htm

Lampe, C., Wohn, D. Y., Vitak, J., Ellison, N. B., \& Wash, R. (2011). Student use of Facebook for organizing collaborative classroom activities. International Journal of Computer-Supported Collaborative Learning, 6(3), 329-347. https://doi.org/10.1007/s11412-011-9115-y

Lenhart, A., Purcell, K., Smith, A., \& Zickuhr, K. (2010, February 3). Social media and young adults. Washington, DC: Pew Research Center. Retrieved from http://www.pewinternet.org/2010/02/03/socialmedia-and-young-adults/

Loh, K. K., \& Kanai, R. (2015). How has the Internet reshaped human cognition? The Neuroscientist, 22(5), 506-520. https://doi.org/10.1177/1073858415595005

Madge, C., Meek, J., Wellens, J., \& Hooley, T. (2009). Facebook, social integration and informal learning at university: 'It is more for socialising and talking to friends about work than for actually doing work'. Learning, Media and Technology, 34(2), 141-155. http://dx.doi.org/10.1080/17439880902923606

Margaryan, A., Littlejohn, A., \& Vojt, G. (2011). Are digital natives a myth or reality? University students’ use of digital technologies. Computers \& Education, 56(2), 429-440.

https://doi.org/10.1016/j.compedu.2010.09.004 
Moisala, M., Salmela, V., Hietajärvi, L., Salo, E., Carlson, S., Salonen, O., ... Alho, K. (2016). Media multitasking is associated with distractibility and increased prefrontal activity in adolescents and young adults. NeuroImage, 134, 113-121. https://doi.org/10.1016/j.neuroimage.2016.04.011

Mok, J. C. H. (2012). Facebook and learning: Students' perspective on a course. Journal of the NUS Teaching Academy, 2(3), 131-143. Retrieved from http://www.nus.edu.sg/teachingacademy/article/lorem-ipsumdolor-2/

Nickerson, R. S. (1998). Confirmation bias: A ubiquitous phenomenon in many guises. Review of General Psychology, 2(2), 175-220. http://doi.org/10.1037/1089-2680.2.2.175

Nouns, Z., Montagne, S., \& Huwendiek, S. (2015). Losing connectivity when using EHRs: A technological or an educational problem. Medical Education, 49(5), 449-451. https://doi.org/10.1111/medu.12722

Oblinger, D. (2003). Boomers, Gen-Xers and Millennials: Understanding the new students. EDUCAUSE Review, 38(4), 37-47. Retrieved from https://er.educause.edu/articles/2003/1/boomers-genxers-andmillennials-understanding-the-new-students

Oblinger, D. \& Oblinger, J. (2005). Is it age or IT: First steps towards understanding the net generation. In D. Oblinger \& J. Oblinger (Eds.), Educating the Net generation (pp. 2.1-2.20). Boulder, CO: EDUCAUSE. Retrieved from http://www.educause.edu/research-and-publications/books/educating-net-generation

Oblinger, D., Oblinger, J. L., \& Lippincott, J. K. (2005). Educating the net generation. Boulder, CO: EDUCAUSE. Retrieved from http://www.educause.edu/research-and-publications/books/educating-netgeneration

Oliver, B., \& Goerke, V. (2007). Australian undergraduates' use and ownership of emerging technologies: implications and opportunities for creating engaging learning experiences for the Net generation. Australasian Journal of Educational Technology, 23(2), 171-186. https://doi.org/10.14742/ajet.1263

Oliver, M. (2011). Technological determinism in educational technology research: Some alternative ways of thinking about the relationship between learning and technology. Journal of Computer Assisted Learning, 27(5), 373-384. https://doi.org/10.1111/j.1365-2729.2011.00406.x

Oliver, M. (2013). Learning technology: Theorising the tools we study. British Journal of Educational Technology, 44(1), 31-43. https://doi.org/10.1111/j.1467-8535.2011.01283.x

Ophir, E., Nass, C., \& Wagner, A. D. (2009). Cognitive control in media multitaskers. Proceedings of the National Academy of Science of the United States of America, 106(37), 15583-15587. https://doi.org/10.1073/pnas.0903620106

Ophus, J. D., \& Abbitt, J. T. (2009). Exploring the potential and perceptions of social networking systems in university courses. Journal of Online Learning and Teaching, 5(4), 639-648. Retrieved from http://jolt.merlot.org/vol5no4/ophus 1209.pdf

Palfrey, J., \& Gasser, U. (2008). Born digital: Understanding the first generation of digital natives. New York, NY: Basic Books.

Papert, S. (1990). A critique of technocentrism in thinking about the school of the future (E\&L Memo no. 2). Cambridge, MA: MIT Media Laboratory. Retrieved from http://cursa.ihmc.us/rid=1N5PWKQGNH47Q0R-37ZW/Papert critique of technocentrism.pdf

Phillips, R., Maor, D., Preston, G., \& Cumming-Potvin, W. (2012). Exploring learning analytics as indicators of study behaviour. In T. Amiel \& B. Wilson (Eds.), EDMEDIA 2012 - World conference on educational multimedia, hypermedia and telecommunications (pp. 2861-2867). Waynesville, NC: AACE. Retrieved from https://www.learntechlib.org/d/41174

Prenksy, M. (2001a). Digital natives, digital immigrants: Part 1. On the Horizon, 9(5), 1-6. https://doi.org/10.1108/10748120110424816

Prenksy, M. (2001b). Digital natives, digital immigrants: Part 2. Do they really think differently? On the Horizon, 9(6), 1-6. https://doi.org/10.1108/10748120110424843

Prensky, M. (2005). Listen to the natives. Educational Leadership, 63(4), 8-13. Retrieved from http://www.ascd.org/ASCD/pdf/journals/ed_lead/el200512_prensky.pdf

Prensky, M. (2009). H. sapiens digital: From digital immigrants and digital natives to digital wisdom. Innovate: Journal of Online Education, 5(3). Retrieved from http://nsuworks.nova.edu/innovate/vol5/iss3/1

Prensky, M. R. (2010). Teaching digital natives: Partnering for real learning. Thousand Oaks, CA: Corwin Press.

Rosen, L. D., (2012). iDisorder: Understanding our obsession with technology and overcoming its hold on 
us. New York, NY: Palgrave Macmillan.

Rosen, L.D., Carrier, L. M., \& Cheever, N. A. (2013). Facebook and texting made me do it: Media-induced task-switching while studying. Computers in Human Behavior, 29(3), 1243-1254. https://doi.org/10.1016/j.chb.2012.12.001

Schawbel, D. (2013, September 4). Why you can’t ignore millennials. Forbes. Retrieved from https://www.forbes.com/sites/danschawbel/2013/09/04/why-you-cant-ignore-millennials/ - 3c9a6fce207c

Selwyn, N. (2009a). The digital native-myth and reality. Aslib Proceedings, 61(4), 364-379. https://doi.org/10.1108/00012530910973776

Selwyn, N. (2009b). Faceworking: Exploring students' education-related use of Facebook. Learning, Media and Technology, 34(2), 157-174. http://doi.org/10.1080/17439880902923622

Selwyn, N. (2012). Making sense of young people, education and digital technology: The role of sociological theory. Oxford Review of Education, 38(1), 81-96. http://doi.org/10.1080/03054985.2011.577949

Smith, E. E. (2012). The digital native debate in higher education: A comparative analysis of recent literature. Canadian Journal of Learning and Technology, 38(3). Retrieved from http://hdl.handle.net/11205/260

Stein, J. (2013). Millennials: The me me me generation. Time, May 2013. Retrieved from http://time.com/247/millennials-the-me-me-me-generation/

Tapscott, D. (1998). Growing up digital: The rise of the net generation. New York, NY: McGraw Hill.

Tapscott, D. (2008). Grown up digital: How the net generation is changing your world HC. New York, NY: McGraw-Hill.

Thompson, P. (2013). The digital natives as learners: Technology use patterns and approaches to learning. Computers \& Education, 65, 12-33. https://doi.org/10.1016/j.compedu.2012.12.022

Trafton, J. G., \& Monk, C. A. (2007). Task interruptions. Reviews of Human Factors and Ergonomics, 3(1), 111-126. https://doi.org/10.1518/155723408X299852

Tripsas, M., \& Gavetti, G. (2000). Capabilities, cognition, and inertia: Evidence from digital imaging. Strategic Management Journal, 21(10-11), 1147-1161. https://doi.org/10.1002/10970266(200010/11)21:10/11<1147::AID-SMJ128>3.0.CO;2-R

Twenge, J. (2012, May 2). Millennials: The greatest generation or the most narcissistic? The Atlantic. Retrieved from https://www.theatlantic.com/national/archive/2012/05/millennials-the-greatest-generationor-the-most-narcissistic/256638/

Xiang, X., \& Liu, Y. (2016). Understanding ‘change’ through spatial thinking using Google Earth in secondary geography. Journal of Computer Assisted Learning, 33(1), 65-78. https://doi.org/10.1111/jcal.12166

Corresponding author: Terry Judd, terry.judd@unimelb.edu.au

Australasian Journal of Educational Technology (C) 2018.

Please cite as: Judd, T. (2018). The rise and fall (?) of the digital natives. Australasian Journal of Educational Technology, 34(5), 99-119. https://doi.org/10.14742/ajet.3821 